\title{
MOGUĆNOSTI KORIŠTENJA ELEMENATA TRADICIJSKE KULTURE U REVITALIZACIJI KRIVOPUTSKOG PODRUČJA
}

\author{
Milana ČERNELIĆ - Marijeta RAJKOVIĆ \\ Filozofski fakultet Sveučilišta u Zagrebu \\ Odsjek za etnologiju i kulturnu antropologiju \\ Ivana Lučića 3, 10000 Zagreb
}

\section{UVOD 1}

$\mathrm{U}$ okviru znanstvenog projekta Identitet i etnogeneza primorskih Bunjevaca pojedine su teme istraživanja izabrane ciljano sa svrhom stjecanja spoznaja o karakterističnim elementima tradicijske baštine ovoga kraja, kao što su: tradicijsko graditeljstvo, gospodarstvo, komunikacije unutar lokalne zajednice i izvan nje (trgovina, sajmovi, transport, opskrba vodom), tradicijsko odijevanje, etnomedicina, tradicijska prehrana, vjerovanja, običaji, pučka pobožnost. Istraživanja su rezultirala spoznajama o stupnju očuvanosti tradicijske baštine Krivoga Puta i pokazala kakvo znanje o njoj imaju pojedini njegovi žitelji. U ovom završnom prilogu namjera nam je ukazati na doprinos i rezultate istraživanja krivoputske tradicijske baštine te predložiti način na koji bi se pojedini njezini segmenti mogli primijeniti u revitalizaciji Krivoga Puta.

\subsection{PREGLED LITERATURE, METODE ISTRAŽIVANJA I OSNOVNA POLAZIŠTA}

Tedan od ciljeva projekta bio je usmjeren i na prepoznavanje i očuvanje tradicijske baštine ovoga kraja te mogućnosti njezine primjene u revitalizaciji ovih prostora kroz održivi razvoj. Da bi se ovo postiglo, potrebno je, među ostalim, spoznajama o zanemarenim tradicijskim vrednotama Krivopućana potaknuti stanovništvo ovoga kraja na pozitivniji stav prema vlastitome kulturnom naslijeđu, ne bi li ih prepoznavanje njegovih pozitivnih svojstava potaklo na inicijativu revitalizacije tradicijske baštine vlastitoga kraja.

Stoga nam je namjera, nakon iznešenih rezultata etnoloških istraživanja na području Krivoga Puta ukazati na ulogu etnologa i na mogućnost primjene istih u razvoju regionalnog turizma kroz vidove ruralnog turizma u senjskom zaleđu na primjeru područja Krivoga Puta. Možda bi u ovom slučaju bilo primjerenije govoriti o ruralnom turizmu u užem smislu, odnosno o agroturizmu ili turizmu na seoskom gospodarstvu, ovisno o kojoj se tradicijskoj aktivnosti radi, budući da su one vezane uz ambijent sela (usp. Baćac 2006:37).

Izvori na kojima se temelje naši prijedlozi jesu dosad objavljeni radovi i prilozi u ovom svesku monografije o pojedinim specifičnim temama spomenutim u uvodu, a koje su istraživane u okviru navedenog projekta. Istraživanja pojedinih tema obavljala su se metodom intervjua (strukturiranih i polustrukturiranih) na temelju pripremljenih upitnika, u razdoblju od 2002. do 2006. godine na području Krivoga Puta i u gradu Senju u kojemu danas živi dobar dio Krivopućana. Autori većine priloga uočili su mogućnost revitalizacije pojedinih segmenata tradicijske kulture Bunjevaca ovoga kraja. ${ }^{2}$ Stjecanjem znanja o njima

Rad je u izmijenjenom obliku objavljen u časopisu Studia ethnologica Croatica vol. 19, str. 245-268.

2 Dio rezultata dosadašnjih istraživanja objavljen je u brojnim prilozima u časopisu Senjski zbornik 30 (2003), 31 (2004), 32 (2005) i 33 (2006) čiji su autori sljedeći: Marijana Belaj, Danijela Birt, Milana Černelić, Jasmina Jurković, Petra Kelemen, Marija Kulišić, Sanja Lončar, Ivana Šarić Žic, Nevena Škrbić Alempijević, Ivana Radovani, Marijeta Rajković, Tihana Rubić, Aleksandra Vlatković, Ivana Vuković, te u časopisu Studia etnologica Croatica vol. 16 (2004) (Vitomir Belaj i Ivana Šarić Žic), vol. 17. (2005) (Milana Černelić), vol. 19 (2007) (Marijana Belaj, Milana Černelić, 
dobiva se osnova na temelju koje se mogu izraditi prijedlozi načina revitalizacije. Takvim se pristupom istraživanju ujedno dobivaju i spoznaje o identitetu stanovništva istraživanog područja, u ovome slučaju primorskih Bunjevaca. ${ }^{3}$ Istraživanje u okviru navedenog projekta pokazalo je kako su tradicijska baština, identitet njezinih nositelja i mogućnosti njene primjenjivosti u suvremenom kontekstu (u budućoj praksi realiziranom kroz oblike ruralnog turizma) blisko povezana i kako suvremena etnološka istraživačka metodologija nužno mora biti holistička. Rezultati takvoga pristupa daju potpuniji uvid i realniju sliku stanja istraživanoga područja i njegove populacije te višestruko doprinose kako u teorijsko-metodološkim promišljanjima, tako i u mogućim praktičnim rješenjima. Teorija i praksa na taj način postaju neodvojive cjeline, a svaka iz svog ugla daje važan doprinos istraživanju odgovarajuće problematike.

Kada bismo se ravnali isključivo prema statističkim podacima o naseljenosti Krivoga Puta tijekom 20. stoljeća, ne bismo niti pokušavali razmatrati mogućnosti realizacije agroturističkih sadržaja na ovome području.

Na temelju podataka iz popisa stanovnistva vidljiv je rast stanovnistva do 1910. godine, da bi nakon tog razdoblja broj stanovnika stalno opadao (...) Otpočela je tiha seoba tzv. socijalna emigracija iz Hrvatske u druge zemlje Austro-Ugarske pa i izvan Europe. Nakon Drugoga svjetskog rata, osobito šezdesetih godina 20. st. seobe se pojačavaju (Ljubović, 2008: 50- 51). ${ }^{4}$

Ovi nas podaci ne trebaju obeshrabrivati jer kroz to razdoblje nije bilo dovoljno poticaja $s$ viših lokalnih i državnih razina za gospodarski razvoj ruralnih, a posebice krševitih područja Hrvatske, što je dugoročno dovodilo do raseljavanja kako u udaljenije zemlje, tako i u gradove, uglavnom u potrazi za osiguravanjem ekonomske egzistencije. ${ }^{5}$ Unatoč tendencijama opadanja naseljenosti Krivoga Puta, dobar dio raseljene populacije svake godine u ljetnim mjesecima boravi u zavičaju kraće ili dulje razdoblje, koristeći neke od pogodnosti života u ruralnoj sredini. Ambijentalne prednosti ruralne sredine, koje postaju sve atraktivnije suvremenim turistima, mogu općenito biti poticajne za smanjenje depopulacije i motivacija povratku stanovništva u depopulirana područja, kao što je slučaj s područjem Krivoga Puta. Poticanje ruralnog turizma može doprinijeti očuvanju ambijentalnosti seoske sredine i zaustaviti njezinu depopulaciju.

Ruralni turizam, tj. potreba za boravkom turista u nenarušenim socijalnim, prostornim i prirodnim okruženjima, postaje okosnica $i$ model ne samo daljnjeg razvoja, već $i$ očuvanja ambijentalnih vrijednosti. Zbog toga se može tvrditi kako je ruralni turizam karika koja može usporiti metamorfozu sela i seoskog okruženja (Baćac 2006:37).

Marijeta Rajković). Također je objavljena etnološko-povijesna monografija Živjeti na Krivom Putu, svezak 1 (2008). Neki od tih radova objavljuju se i u ovoj Monografiji.

3 O identitetu primorskih Bunjevaca vidi više u: Škrbić Alempijević (2004) i Černelić (2005).

4 Više o demografskim prilikama na području Krivoga Puta u 19. i 20. stoljeću vidi u Ljubović (2008), te Husanović Pejnović i Pejnović u ovom svesku Monografije. O migracijama stanovništva Krivoga Puta i njihovim uzrocima vidi i u Rajković (2004).

5 Neke inicijative u tom razdoblju rapidne depopulacije Krivoga Puta od strane lokalne zajednice tiču se poboljšanja demografskog i gospodarskog stanja u regiji. Vapaj za spas Krivoga Puta upućen je sa sastanka u zadružnom domu Krivoga Puta 10. 11. 1970. godine pod znakovitim naslovom Hoće li se u planinsko selo blizu Senja vratiti izgubljeni sinovi? Nove nade za Krivi Put. (Večernji list 1970:6). O sličnoj problematici govori i članak pod naslovom Senjcentar za preradu mlijeka? objavljen u Vjesniku 2. 4. 1970. godine (Vjesnik 1970:6). Bilo je čak i inicijative za razvoj turizma turistima bi se omogućilo "kupanje u moru, a spavanje na gorskom zraku" (usp. Ljubović, 2008). Te inicijative ipak nisu urodile plodom pa depopulacija nije zaustavljena.

6 Prema posljednjem popisu stanovništva iz 2001. godine, u općini Krivi Put živi 233 stanovnika (usp. Rajković 2004: 266). 
Revitalizacija pojedinih segmenata tradicijske kulture Krivoga Puta mogla bi se ostvarivati kroz razne specifične izvorne i ambijentalne značajke ovoga kraja, koje su, premda zapuštene, u nekim oblicima sačuvane. Na temelju rezultata istraživanja izdvajamo te značajke iz različitih područja života te predlažemo moguće načine njihova uključivanja u turističku ponudu: načine revitalizacije tradicijskog graditeljstva, oživljavanje kvalitetnim i primjerenim prenamjenama da bi se zadovoljile potrebe suvremenog života, a uz uvjet očuvanja karaktera i integriteta same arhitekture; načine organizacije sudjelovanja turista u oblicima tradicijskog gospodarstva sa specifičnim značajkama načina života ove zajednice, koje se mogu iskoristiti kao turistička atrakcija (primjerice obilazak i boravak u ljetnim stanovima); načine na koje se specifični tradicijski oblici transporta mogu oživjeti za turističke potrebe (jahanje na magarcu, vožnja zaprežnim kolima ili zimi vožnja saonicama); uključivanje karakterističnih tradicijskih jela u turističku ponudu; kroz pozitivne primjere upotrebe ljekovitog bilja uključivanje elemenata narodne medicine u suvremeni život, odnosno načine na koje ih kroz praktičnu primjenu i kroz stvaranje prepoznatljivih proizvoda i suvenira uključiti u turističku ponudu ovoga područja; način prezentacije elemenata iz materijalne kulture u vidu "eko-etno suvenira"; načine povezivanja lokalne proslave blagdana Majke Božje Snježne i Senjskog karnevala s kalendarom turističkih zbivanja na ovome području. Sve istražene značajke, aktivnosti i događanja odraz su načina života lokalnog stanovništva što je neophodno za samu ideju ruralnog turizma, imajući u vidu jednu od mogućih definicija toga pojma koja kaže da je:

Ruralni turizam - seoski turizam je oblik turizma u kojem se podrazumijeva povremeni boravak turista u seoskoj sredini; posjetiteljima, osim čistog zraka i prirodnog ambijenta, pruža različite mogućnosti aktivnog sudjelovanja u životu $i$ radu seoskog gospodarstva (Vukonić, Čavlek prema Baćac 2006:37).

Pri formuliranju prijedloga za revitalizaciju segmenata tradicijske baštine Krivoga Puta vodi se računa o smjernicama za prepoznavanje turističke atrakcijske osnove kako ih je osmislio Eduard Kušen, ponajviše one u poglavlju o kulturi života i rada, te ćemo u daljnjem tekstu predstaviti atrakcijske resurse senjskoga zaleđa $(2002: 27,102)$.

Turistički resursi su prirodna ili antropogena dobra koja se mogu iskorisiti (valorizirati). Dio su cjeline razvoja odredenog geografskog područja, odnosno regije ili zemlje, a bogatstvo resursima komparativna je prednost u gospodarskom razvoju (...) Turistički resursi moraju imati visok stupanj privlačnosti, kako bi svojim svojstvima i karakteristikama privukli odredeni segment turističke potražnje. Cjelokupna ponuda u turizmu zemlje morala bi se temeljiti upravo na atraktivnim svojstvima kojima ona raspolaže. Turistički se resursi prema genetskom porijeklu klasificiraju na prirodne (biotropne) i antropogene (atropične). Prirodni mogu biti klimatski, geomorfološki, hidrografski, biogeografski i pejzažni, a antropogeni su kulturno-povijesni, etnosocijalni, manifestacijski, umjetnički i ambijentalni (Kušen 2006:44).

Naši se prijedlozi uglavnom temelje na antropogenim svojstavima istraženoga područja koja su po našoj ocjeni dovoljno atraktivna da bi bila uključena u turističku ponudu šireg područja senjskoga zaleđa. Jednako su atraktivni i prirodni resursi ovoga kraja koji, međutim, nisu predmet našeg istraživanja.

U sljedećem ćemo poglavlju predstaviti mogućnosti njegove revitalizacije i uključivanja u nacionalni program razvoja ruralnog turizma u Hrvatskoj. 


\section{REZULTATI ISTRAŽIVANJA I PREDSTAVLJANJE ATRAKCIJSKIH RESURSA KRIVOGA PUTA}

\subsection{TRADICIJSKO GRADITELJSTVO}

$\mathrm{D}$ oprinos poznavanju tradicijskog graditeljstva i kulture stanovanja na području Krivoga Puta daju radovi Ivane Šarić Žic $(2006,2008)$. Autorica razmatra graditeljstvo ovoga područja kao jednostavno i funkcionalno. Osnovni građevni materijali su kamen i drvo. Definirajući karakteristike graditeljskog naslijeđa na području Krivoga Puta i njegove okolice, razlikuje dva osnovna tipa prema načelu korištenja prostora: prostor namijenjen zajedničkom obitavanju ljudi i stoke te prostor namijenjen njihovu zasebnom obitavanju. U tradicijskoj okućnici vidljivi su pojedini arhitektonski elementi, primjerice bajte (ljetne kuhinje), šterne (vodospreme), trapovi za spremanje zimnice.

Autorica je uočila očuvanost tradicijskog graditeljstva koje se, u pozitivnom smislu, značajno razlikuje u odnosu na priobalni prostor. Budući da je po struci etnologinja, koja je u vrijeme istraživanja bila zaposlena pri Konzervatorskom odjelu u Rijeci, u njezinu su radu dane smjernice i modaliteti zaštite te upozorenje na moguće posljedice nekontroliranih sanacija i rekonstrukcija:

Jedan od suvremenih koncepata očuvanja graditeljske baštine jest njezina revitalizacija, odnosno «oživljavanje» kvalitetnim i primjerenim prenamjenama, kako bi se zadovoljile potrebe suvremenog života, uz uvjet očuvanja karaktera $i$ integriteta same arhitekture. Zbog gubitka funkcije koju su nekada imale i nenalaženja nove, te su gradevine izložene sve rapidnijem propadanju. Stoga im je, kako bi se očuvala njihova ambijentalna $i$ arhitektonska vrijednost, potrebno dati nove sadržaje, primjerice u okvirima agro i ekoturizma. Medutim, pri tim prenamjenama valja biti vrlo pažljiv kako one ne bi rezultirale gubitkom vrijednosti same arhitekture. (...) Revitalizacija tih prostora podrazumijeva i infrastrukturnu rekonstrukciju, što bi omogucilo stvaranje prihvatljivog okvira za kvalitetnu turističku valorizaciju. To uključuje vodoopskrbnu mrežu kao i bolju prometnu povezanost. A ono što tom prostoru, uz očuvanu tradicionalnu arhitekturu, daje iznimnu vrijednost, kulturni je krajolik s brojnim suhozidima, na čijem je očuvanju takoder potrebno ustrajati (2006:373-374).

U tradicijskoj arhitekturi zanimljive su razlike između kuća za stalni boravak stanovništva i nastambi za sezonski i ljetni boravak. ${ }^{7}$

\subsection{TRADICIJSKO GOSPODARSTVO}

Turizam povezan (...) sa seoskim načinom života pokazao se jednostavnom i logičnom mogućnošću prezentiranja ruralnih sredina (Baćac 2006:36).

$\mathrm{Na}$ širem području senjskoga zaleđa još uvijek postoje seoska gospodarstva, a u pojedinim je predjelima tradicijsko gospodarstvo detaljno istraženo ${ }^{8}$, što daje dobre osnove za razvoj ovog oblika turizma. ${ }^{9}$ Osnovne su gospodarske grane u Krivome Putu bile stočarstvo i zemljoradnja, a pojedinci su se bavili kirijanjem (izvlačenjem drvenih trupaca iz šume), obrtništvom (stolari, kolari i kovači), lovom na divlje životinje te pčelarstvom. Posjedovali su po nekoliko jutara zemlje, ponajviše u obliku oranica i livada koje su se obrađivale i kosile. Osim samog boravka i sudjelovanja u svakodnevnom gospodarskom životu ovoga kraja (hranjenju domaćih životinja, mužnji krava, čuvanju ovaca) atrakcijske resurse predstavljaju i gospodarske djelatnosti u čijoj je izvedbi sudjelovao veći broj članova lokalne zajednice - poput žetve

Više o tome vidi u Rajković $(2005,2008)$.

8 Više o tradicijskom gospodarstvu vidi u prilozima Marijete Rajković u prvome svesku Monografije, str. 157- 278. (2008).

9 Više o turizmu na seoskom gospodarstvu vidi u: Baćac 2006. 
žita (za ovo područje ječma i zobi), vršenja žita na volovima, konjima pa i magarcima. Sjenokoša je imala iznimnu važnost u životu stanovnika ovih predjela. Za turiste bi bilo atraktivno demonstriranje žetve žita pomoću srpa (žene) te košnje trave (muškarci), a oni sami mogli bi sudjelovati u radu, natjecati se i sl. Osim sudjelovanja u pojedinim poslovima (sadnja krumpira i zelja), turistima bi se moglo ponuditi da kupe domaće prehrambene proizvode iz ekološke proizvodnje. Također bi mogli pohađati školu jahanja, ili iznajmljivati konje za jahanje. Osim konja atrakcija bi mogla biti i jahanje na magarcu.

Specifičan sezonski način života Krivopućana također bi bio zanimljiv turistima, kojima bi se moglo omogućiti da borave u kućama u kojima njihovi domaćini stalno žive i u kojima su iz gospodarskih razloga boravili ljeti (ljetnim stanovima), gdje bi im bilo zanimljivo ložiti vatru na otvorenom ognjištu, spremanje hrane pod pekom, kuhanje u kaštroli i sl. Na području Krivoga Puta ima sačuvanih ljetnih stanova, ponekih zaraslih travom i grmljem u naseljima u kojima danas nitko ne živi (na primjer Šušanj), ali i takvih u koje vikendom i za vrijeme godišnjih odmora ljudi zadnjih godina dolaze sve više. Šteta im je to zapustit. Ljudi što su stariji, to ih valjda sve više vuče neka nostalgija za tim rodnim krajem, prema riječima Milana Tomljanovića Livaka iz Bunice. Njegov je djed imao ljetni stan na Vrataruši, no kako je bio u ruševnom stanju, srušili su ga. Trenutno na istome mjestu, sa sestrom koja živi u Njemačkoj, gradi kuću od kamena, u istom stilu kakva je nekada bila (usp. Rajković 2005:307, Rajković 2008: 159-183). ${ }^{10}$

Na lovištu Senja obitavaju: srna, divlja svinja, medvjed, zec obični, kamenjarka, divlja mačka, jazavac, kuna zlatica, kuna bjelica, lisica, tvor, šojka, vrana siva, divlji golub pećinar, vuk, ris, prepelica pućpura (usp. Jurčenko et al. 2005:37-38). Od devedesetih godina 20. stoljeća lov je postao turistička ponuda senjskog zaleđa. Uglavnom dolaze inozemni lovci iz Austrije, Švicarske, Njemačke i Italije. Dolazak inozemnih turista odražava se i na gospodarstvo Senja međutim to je veoma neznatno prema kazivanju Milana Vukelića Devize koji je objasnio: Tereni nisu veliki, nije velika kvota odstrela, medutim odredeni dio njih dolazi s obiteljima i prijateljima ponovno ljeti na godišnji odmor. Tako nastaje lančana reakcija koja doprinosi turističkoj dobiti. Naš prijedlog, sa stajališta etnologije bio bi da se u turističku ponudu uvrsti prezentacija tradicijskog načina lova, te prepričavanjem priči i anegdota za djecu, s ciljem upoznavanja raznih životinja i njihova načina života. Kada već dolaze odrasli lovci da ostali dio godine povedu i članove obitelji, za što je dakako potrebno proširiti turističku ponudu. ${ }^{11}$

\subsection{PRIJEVOZ I OPSKRBA VODOM}

Secifičan način života na planinama, stanovanje na dvije ili tri nadmorske visine ovisno o godišnjem $\checkmark$ dobu i vremenskim prilikama te nepristupačnost terena uvjetuju upotrebu odgovarajućih transportnih sredstava. U seobama, u kojima se često prenosila gotovo čitava imovina, za transport su upotrebljavani magarci i mule, a u kasnijim razdobljima zaprežna kola. Na magarcima, mulama, odnosno samarima, Bunjevci Krivoga Puta dopremali su s planine sijeno, drva, krumpir i žitarice, a u grad transportirali namirnice za prodaju. Izgradnjom putova do važnijih naselja u širu uporabu ulaze zaprežna kola koja najčešće vuku konji i volovi i koja se i danas upotrebljavaju. Zimi su se uglavnom koristile saonice. ${ }^{12}$ Sve ove vrste transportnih sredstava mogu se iskoristiti kao turistički resurs.

Pitka voda i danas je problem stanovnika planinskih sela u senjskoj okolici. Njezin nedostatak bio je jedan od razloga iseljavanja. Najvažniji i najobilniji izvori vode u senjskoj okolici nalaze se u Senjskoj Dragi iz koje se do 1969. godine opskrbljivao i grad Senj. Osim ovih izvora, postoje i izvori manjeg kapaciteta

10 Taj dio turističke ponude bio bi još atraktivniji u području velebitskog Podgorja, gdje su podgorski Bunjevci u pravilu imali tri stalne naseobine: jednu blizu mora, drugu na oko 600-800 m nadmorske visine i treću pod samim vrhovima Velebita. Inicijativu za obnovu ljetnih stanova i za njihovo korištenje u turističke svrhe podupiru i djelatnici Nacionalnog parka "Sjeverni Velebit". Da bi se takav vid turizma ostvario, bilo bi potrebno revitalizirati i planinarske staze koje bi uključivale razgledavanje ljetnih stanova.

11 Više o tradicijskom i suvremenom lovu vidi u istoimenom prilogu Marijete Rajković u prvom svesku Monografije, str. 265-278.

12 Više o prijevozu i prijevoznim sredstvima vidi u prilogu Danijele Birt, u prvome svesku Monografije, str. 281-306. 
koji su se upotrebljavali za opskrbu lokalnog stanovništva, a koje bi turisti mogli razgledavati. Spominju se u predaji i grčki bunari, jedan kod Klaričevca, za koji se tvrdi da je i za vrijeme najveće suše u njemu bilo vode, te na području Podbila: Dražica na Alijinom bilu na mjestu kojega je Alija, turski vojskovođa, po predaji, slomio nogu i Štura na Pekinom Dolcu ${ }^{13}$. Putove do tih bunara trebalo bi prokrčiti i osposobiti za turističke obilaske, a predaje vezane uz njih turistima bi sigurno bile zanimljive. U ranijim su razdobljima ovi izvori bili jedina vodoopskrbna mjesta od kojih se voda vozila i na udaljenosti veće od $20 \mathrm{~km}$. Kako je velika udaljenost od izvora otežavala život i rad, Bunjevci su kroz povijest koristili prirodne osobitosti terena i izrađivali različite vodoopskrbne sustave. Kao najpoznatiji prirodni vodoopskrbni sustav u planinskim dijelovima koristile su se tzv. snježnice, snižnice, špilje ili jame u kojima bi se tijekom čitave godine sačuvao snijeg napadao tijekom zime. U ljetnim mjesecima sleđeni se snijeg rezao na kocke i prevozio do ljetnih stanova te upotrebljavao za piće i napajanje stoke. Od druge polovice 19. stoljeća počinju se graditi šterne (cisterne), najprije u tehnici suhozida s nepropusnim slojem od gline (ilovače), a poslije uporabom modernih građevinskih materijala, kojih iz različitih razdoblja ima mnogo na Krivome Putu.

Razgledavanje postojećih obiteljskih šterni i sudjelovanje u njihovoj izgradnji bila bi turistička atrakcija, kao i razgledavanje većih tzv. državnih šterni, kojih najčešće ima po jedna ili dvije za svako naselje.

Turistima s avanturističkim duhom i sklonosti prema planinarenju mogao bi se ponuditi odlazak $s$ lokalnim vodičem na snižnicu i do ostalih izvora vode.

Za transport vode i pri obavljanju poslova u polju i šumi koristile su se drvene posude - bačve, barilci, burila (burla) i žbanjice - koje bi se u manjim dimenzijama mogle izraditi kao suveniri s praktičnom primjenom, na primjer za čuvanje hrane u kućanstvu (tekućina, začina). Ujedno bi se na taj način pridonijelo revitalizaciji obrtništva. Također, moglo bi se upriličiti demonstriranje obrade drveta da bi se turisti upoznali s načinom izrade tih predmeta, ali i u obliku radionica u kojima bi mogli aktivno sudjelovati. ${ }^{14}$

\subsection{TEKSTILNO RUKOTVORSTVO}

$T$ ekstilno rukotvorstvo nudi, također, velike mogućnosti u turizmu. Glavna sirovina za izradu odjevnih predmeta bila je vuna. Nakon šišanja ovaca i janjadi vuna se prala i dijelila na ovčju i janjeću. Janjeća je bila mekša te se upotrebljavala za izradu svečanije odjeće. Ovčja je bila grublja i upotrebljavala se za izradu svakodnevne odjeće, šarenica (pokrivača za krevete i zid) i biljaca (vunenih pokrivača). Poslije pranja i dijeljenja vuna se čupala rukama i vlačila na gargaše (češljeve), što se obično radilo na prelima. Tako obrađena vuna motala se u kudilju (smotuljak), zatim prela i motala u klupka. Ako je vunu trebalo bojati, motalo ju se na raškove (štapove visine oko $1 \mathrm{~m}$ koji na jednome kraju imaju horizontalnu daščicu, a na drugome prirodnu rašlju). U ranijim razdobljima vuna se bojala (strojila, mastila) prirodnim bojama dobivenim od orahova lišća i kore, duhana, jasenove kore, rušvice (grmolike biljke) dok se u novijim razdobljima za bojanje upotrebljavala industrijska boja, koja se nabavljala u Senju (usp. Vlatković 2003, te u ovom svesku Monografije). Osim vune, za proizvodnju odjevnih predmeta koristili su se lan i konoplja, od kojih su izrađivane ženske donje košulje, muške donje gaće, plahte, posteljina i ručnici te koža za izradu kožuna i šubara. Od kože se izrađivala i obuća, posebice opanci.

Osim prezentacije načina obrade sirovina te mogućnosti organiziranja radionica, svaki upotrebni tekstilni predmet mogao bi se izrađivati za prodaju, u svojoj primarnoj funkciji ili prilagođen suvenirskoj ponudi. Primjerice, kao karakteristični muški odjevni predmeti mogu se izdvojiti: ćurak (kratki kaput dužine do bokova), ječerma ili čerma (prsluk), pletene maje (džemperi s rukavima), puloveri (pleteni džemperi bez

13 Više o opskrbi vodom vidi u prilozima u prvome svesku Monografije, Danijele Birt i Matije Dronjića, str. 307-322.

14 Takve drvene posude izrađivale su se izvan Krivoga Puta, u Kutarevu, a prodavale su se na sajmovima u Otočcu i Brinju, a i sami Kutarevci su s natovarenim kolima prolazili selom i prodavali ih. Osim tradicijskog rukotvorstva u drvetu, za što bi svakako u Kutarevu trebao biti vezan i jedan od ogranaka eko-muzeja, gdje su još i danas ovi stari zanati vrlo živi; u daljnjoj budućnosti mogli bi se revitalizirati proizvodi kovačije, lončarstva i košaraštva. Vidi više o Kutarevcima u prilogu Tihane Rubić u prvome svesku Monografije, str. 344-346. 
rukava), manice, zašaknjače, narukvice (odjevni predmet koji se navlačio preko maje i nosio na ruci od šake do lakta), odjevni predmet poput nogavica koji se nosio preko hlača na potkoljenicama - za koji se koriste različiti nazivi poput natikače, štrimfe, štumfarice, nakoljenice - a služio je za sprečavanje prodora snijega u nogavice; tu su još čarape od vune, kožun i šubara (usp. ibid. 599).

Budući da su se odjevni predmeti domaće proizvodnje već početkom 20. stoljeća počeli gubiti sovoga područja, za turističke bi ih potrebe trebalo rekonstruirati na temelju rezultata provedenih istraživanja i uz pomoć žena koje neke od predmeta još i danas izrađuju i koriste, na primjer štramce, biljce, krpare i sl.

\subsection{TRADICIJSKA PREHRANA}

$\mathrm{B}$ udući da su se Bunjevci na Krivome Putu uglavnom bavili stočarstvom, prehrana im je bila bazirana na mlijeku i mliječnim proizvodima: kiselom mlijeku - kiselini, siru i putru. Kiselina se najčešće jela s palentom, ali i samostalno. Poznat je u ovome kraju sir škripavac kojemu ovdje dodaju atribut bunjevački, a inače je poznat i šire u Lici. Stanovnici ovoga kraja objašnjavaju da se škripavac čuje pod zubima, i upravo škripi (Jurković 2004:197). Putar se pravio metenjem skupljenoga skorupa (slake) u drvenom stapu uz pomoć mećaje (usp. ibid.:189-212).

Druga je neizostavna namirnica ovoga kraja bio krumpir, iznimno cijenjen zbog podneblja pogodnog za njegovu proizvodnju i kvalitetne zemlje. Najčešća jela od krumpira bila su: pečene polovice krumpira na koje su stavljali ploške slanine i češnjak - pole ili police; krumpirova palenta (tzv. krumpirice) koja se jela i uz kiselo mlijeko (kiselinu). Vrlo često jelo na bunjevačkome stolu je i kiseli kupus; osobito su zastupljene dvije vrste jela: zelje gra i zelje meso, po ocjeni kazivača Marka Pavelića Mijatine to je bio božji ručak (ibid. 202). Kruh od ječma i pšenice pekao se pod pekom, a od šezdesetih godina 20. stoljeća u rolu (štednjaku). Od suhomesnatih proizvoda najzastupljeniji je pršut te dvije vrste kobasica (mesne kobasice i krvavice) koje su Krivopućani koristili u posebnim prilikama, za vrijeme većih ljetnih poslova i za goste.

Tradicijska je posebnost i rakija od samoraslog grma šmrike, tzv. šmrikovača. Pojedinci koji su imali pčele izrađivali su šerbet (piće od prokuhanog saća). Slastice su bile rijetke, sadilo se malo voćaka, ali se dosta koristilo samoniklo bilje i bobice. Od šumskih plodova izrađivali su slatka pića među kojima su najpoznatiji malinovac i trambuva (usp. ibid.) ${ }^{15}$. Na ovim je prostorima danas razvijeno pčelarstvo, posebice med od kadulje i vriska koji imaju i ljekovita svojstva, osobito za plućne bolesti i bronhitis ${ }^{16}$. Jasmina Jurković zaključuje:

Unatoč ekonomskoj nestabilnosti, ističe se nekadašnji zdrav način prehrane koji je, prema mišljenjima kazivača, u današnjoj prehrani slabo zastupljen. Zbog sve većeg značenja svjetskoga turističkog opredjeljenja za zdravu i domaću hranu, današnja prehrana nastoji objediniti namirnice $i$ jela tradicijskih kuhinja. Takvim nastojanjima svakako pridonose sustavna terenska istraživanja, prikupljanje te sintetiziranje grade kao i konačno objavljivanje radova u sklopu znanstvenih projekata, kao što je ovaj o primorskim Bunjevcima (ibid. 207).

Saznanja o tradicijskoj prehrani nude mogućnost njihove primjene i u suvremenim uvjetima. Dijelom je ona i danas prisutna u svakodnevnoj prehrani. Stoga ovaj kraj ima potencijala da ponudi originalan gastronomski turistički proizvod svojim posjetiteljima.

\subsection{NARODNA MEDICINA}

sim spomenutog meda, na obroncima Velike Kapele narodna medicina i danas čini važan segment svakodnevice. Krivopućani koji tu žive, ali i oni koji su se odselili u Senj, odlaze u potragu za ljekovitim travama od kojih pripremaju razne ljekovite pripravke. Spomenimo samo najzastupljenije biljke:

$\overline{15}$ Više o tradicijskoj prehrani vidi u prilogu Jasmine Jurković o tradicijskoj prehrani u ovom svesku Monografije.

16 Više o pčelarstvu vidi u prilogu Marijete Rajković u prvom svesku Monografije, str. 249-264. 
majčina dušica (za pluća), bukvica (trputac - za liječenje posjekotina), gospina trava (u kombinaciji s maslinovim uljem stavlja se na posjekotinu), kamilica (za upalu očiju), metvica (za želudac).

Živa su sjećanja na proizvodnju ljekovitih masti, primjerice od jazavca i puha (za posjekotine) i od nevena (za rane, vene, kožu). U članku o narodnoj medicini stanovništva Krivoga Puta Petra Kelemen zaključuje sljedeće:

Poznavanje ljekovitih trava i postupaka koje su ljudi prakticirali u slučajevima bolesti, kao i odnosi poštovanja prema osobama koje su poznavale pojedine načine liječenja, govore da je narodna medicina bila važan segment života stanovnika ovog kraja. Neki elementi narodne medicine žive $i$ danas i uspješno su uklopljeni u vrijeme u kojem je službena medicina pristupačnija ... Naime, uslijed iseljavanja stanovnistva, ali $i$ bolje povezanosti s ostalim krajevima te lakšeg dolaska do potrebnih lijekova i liječnika, narodna medicina gubi primat koji je do tada imala. No, pozitivni primjeri upotrebe ljekovitog bilja pokazuju mogućnosti uključivanja elemenata narodne medicine u suvremeni život, kako kroz praktičnu primjenu, tako i kroz stvaranje prepoznatlivih proizvoda i suvenira $i$ njihovoga uključivanja u turističku ponudu ovoga područja ${ }^{17}$.

Osim izleta na više nadmorske visine u potrazi za ljekovitim biljem, segmenti tradicijske medicine mogu se, također, prezentirati u obliku suvenira, a više znanja o njima zainteresirani turisti mogli bi steći preko organiziranih radionica.

\subsection{PUČKA POBOŽNOST I OBIČAJI}

\subsubsection{OBILJEŽAVANJE BLAGDANA MAJKE BOŽJE SNJEŽNE}

Tajka Božja Snježna lokalna je zaštitnica Krivoga Puta kojoj je u čast 1856. godine podignuta crkva 1 u Podbilu ${ }^{18}$. Njezin je blagdan 5. kolovoza. Proslava toga blagdana danas je veoma živa jer tada mnogi raseljeni Krivopućani, iz bližih i udaljenijih krajeva, dolaze u zavičaj pa je ovaj blagdan postao dan susreta stalnih i iseljenih stanovnika toga područja. Uz pobožni, blagdan ima i svjetovni karakter ${ }^{19}$. Pobožnost se sastoji od hodočašća, procesije s Gospinim kipom, molitava, mise i zavjetovanja za rješavanje raznih životnih problema, osobito zdravstvenih.

Popratne manifestacije imaju društveno-zabavni karakter: svira glazba uživo cijeli dan do kasno u noć, odnosno do jutra, peku se janjci, postavljeni su štandovi s jelom, pićem, predmetima vjerskoga, ali i svjetovnog sadržaja, do Drugoga svjetskog rata bilo je uobičajeno plesanje kola ispred crkve, organizira se nogometni turnir u kojemu, uz lokalnu momčad NK Bunjevac, sudjeluju gostujuće momčadi (usp. Kulišić - Vuković 2004).

Ova manifestacija, koja se održava ljeti u vrijeme turističke sezone, predstavlja također potencijalni atrakcijski resurs ovoga kraja. Uz obnavljanje nekih karakterističnih tradicijskih sadržaja, primjerice, plesanja bunjevačkog kola na petunu (prostoru ispred crkve) te zamjene ili nadopune prodajnih artikala na štandovima sa suvenirima s lokalnim obilježjima, ova živuća tradicija Krivoga Puta lako bi se mogla uvrstiti u turističku ponudu i na taj način pridonijeti raznovrsnosti turističke ponude ovoga kraja.

17 Više vidi u prilogu Petre Kelemen o narodnoj medicini, u ovom svesku Monografije.

18 Više o Župi Krivi Put vidi u prilogu Mile Bogovića u prvom svesku Monografije, str. 69-78.

19 Više o obilježavanju spomendana Majke Božje Snježne vidi rad Kulušić i Vuković (2004), te prilog u ovoj monografiji, a o dolasku raseljenih Krivopućana u prilogu Pregled migracija Krivopućana, Marijete Rajković u prvom svesku Monografije, str. 79-94. 


\subsubsection{KRIVOPUĆANI I SENJSKI KARNEVAL}

$\mathrm{B}$ udući da je tradicija pokladnih ophoda na Krivome Putu od sedamdesetih godina 20. stoljeća bitno prorijeđena, ponajviše zbog nedostatka mlađe populacije, Krivopućani su postupno počeli sudjelovati u Senjskome ljetnom karnevalu. Primorskom Bunjevcu je u diskursu senjskog karnevala nerijetko dodijeljen identitet lakovjerne žrtve pokladnih vragolija razularene gradske mladeži (na primjer, Pero iz senjske planinske okolice nasjeda na predstavljanje Senjanina spolno inverzno prerušenog u "Emiliju"). Pokladna zbivanja mjesto su na kojemu se nesputano iskazuje opozicija između gradskoga i seoskog stanovništva, koja je odraz različitog načina života dviju susjednih zajednica, kao i razlika u prakticiranju pokladnih običaja. Dok su krivoputske poklade imale luperkalijsku (magijsku) komponentu, senjski karneval (i ljetni i zimski) pripada saturnalijskom tipu karnevala, gradskom, s naglašenom društveno-kritičkom komponentom (usp. Lozica 1997:192-195). U svom prikazu krivoputskih i senjskih karnevala Nevena Škrbić Alempijević daje prikaz interakcije urbanih i ruralnih pokladnih sadržaja, bolje reći napuštanjem ruralnih sadržaja dolazi do njihova postupnog prilagođavanja urbanim karnevalskim događanjima ${ }^{20}$.

O uključivanju Krivopućana u senjski karneval N. Škrbić Alempijević zaključuje:

Nerijetko se i stanovnistvo još uvijek naseljeno na Krivom Putu tijekom karnevalskih dogadanja spušta u grad te se, prerušeni, priključuju povorci mačkara ili je barem prate iz publike. U tom se trenutku odnos bunjevačkih i senjskih pokladnih ophoda prestaje izražavati s nizom suprotnosti, kojima se urbana sredina nastoji simbolički razgraničiti od svoje ruralne okolice; senjski karneval u ovom slučaju omogućuje i širu, regionalnu identifikaciju. (...) Sudjelovanje stanovnika s Krivoga Puta u senjskim karnevalima možemo pratiti (barem) iz dvije perspektive. Jedno polazište predstavlja kulturna praksa iseljenoga bunjevačkog stanovništva trajno nastanjenog u tom gradu. Za njih senjski karneval postaje obilježjem njihove nove lokalne identifikacije i interakcije sa sredinom čiji segment danas čine. Drugo su Krivopućani koji se redovito na karnevalske dane iz svojih rodnih sela spuštaju u grad. Time oni senjske karnevale, zimske i ljetne, transformiraju u zgode koje zauzimaju istaknuto mjesto u primorskobunjevačkom godišnjem kalendaru, u dogadanja u kojima bi bilo "grijeh ne sudjelovati", u običaje koje krivoputska zajednica počinje poimati kao podjednako svoje (2006: 397, 401).

Senjski karnevali, osobito ljetni, zaživjeli su kao svojevrsna turistička atrakcija u gradu Senju. Na temelju spoznaja o pokladnim običajima u zaleđu Senja i o njihovoj povezanosti s pokladnim događanjima u gradu, može se turistička ponuda vezana uz tu manifestaciju obogatiti novim sadržajima, omogućiti turistima jedan drugačiji doživljaj karnevala, u svoj njegovoj raznovrsnosti, kroz opoziciju i interakciju ruralnih i urbanih sadržaja.

\subsubsection{PRELO}

$\mathrm{P}$ remda prelo, kao sastanak mladih, koji se sastoji od radnog i zabavnog dijela, danas više nije živuća tradicija (kao takva održavala se u zimskim mjesecima do šezdesetih godina 20. stoljeća), u sjećanju kazivača ona je još živa. Zahvaljujući tome, prelo bi se moglo rekonstruirati, i na taj način višestruko prezentirati kulturna baština kraja preko sadržaja koji su u prelima zastupljeni: ples (vrste tradicijskih kola), tradicijski instrumenti (usna citara, tamburica), pjesme bećarci, zagonetke, igre, tradicijski poslovi (čijanje perja, čupanje vune, a kao rezultat tih poslova mogli bi se izrađivati tradicijski odjevni predmeti ili se izrađivati kao suveniri za prodaju). Na taj način bi prelo moglo postati dio programa razvoja zimskoga turizma. Turisti bi mogli postati sudionici samoga prela, uključivanjem u neke aktivnosti karakteristične za prelo, bilo radnog bilo zabavnog karaktera. ${ }^{21}$

20 O tome vidi više u prilogu Nevene Škrbić-Alempijević i Aleksandre Vlatković u ovom svesku Monografije.

21 Više o prelima vidi u knjizi o svadbenim običajima Krivopućana (u tisku). 


\section{ZAKLJUČNA RAZMATRANJA}

$\mathrm{T}$ erenski obilazak područja Krivoga Puta za potrebe istraživanja u okviru projekta Identitet i etnogeneza primorskih Bunjevaca potvrdio je da to područje obiluje brojnim prirodnim i antropogenim resursima. Rezultati prikazuju, a tome svjedoče i ova dva opsežna sveska monografije, kako su na području Krivoga Puta još relativno dobro očuvane ambijentalne vrijednosti, posebice tradicijska arhitektura i segmenti drugih pojava iz tradicijskog života, a osim toga i živo sjećanje njihovih žitelja na tradicijski način života. Istraživanja su, dakle, pokazala da ovaj kraj može ponuditi originalan turistički proizvod i da ima potencijala za različite vidove ruralnog turizma.

Agroturizam (...) povezuje tradicionalne vrijednosti i dostignuća te ih uopćava u turistički proizvods naglašenom karakteristikom ambijentalnosti i antropomorfnosti, odnosno očuvanja povijesnih područja s izrazito tradicionalnom arhitekturom koja zajedno s prirodnim okruženjem čini područja izrazito vizualno prihvatljivima i atraktivnima. Nesumnjivo je da se upravo na takvim područjima stvara antropomorfni turizam, odn. turizam 'po mjeri čovjeka', koji je u skladu s prirodom, okruženjem i prevladavajućim načinom života (Baćac 2006:39).

Prezentacija atrakcijskih resursa Krivoga Puta pokazala je kako ovaj kraj ima sve potrebne agroturističke potencijale.

Rezultati istraživanja ukazali su, također, na važnost uloge etnologa u dijagnosticiranju stanja i potencijala tradicijske baštine, kao i na mogućnost njezine iskoristivosti u turističkoj ponudi. Drugim riječima, etnolog ima što doprinijeti razvoju i realizaciji ruralnog turizma u svim njegovim vidovima. Kada govorimo o segmentima tradicijske kulture, etnolozi u njoj mogu prepoznati proizvode, aktivnosti, manifestacije, pomoći da oni budu prezentirani, potom i revitalizirani u svojemu autentičnom i autohtonom obliku.

Duh prostora ne čine samo ljepote pejzaža i povijesne znamenitosti, već i karakter ljudi, običaji, način života, način ishrane, vizualna očuvanost ambijenta i ostali detalji (ibid.).

Na sve te detalje u našim istraživanjima na području Krivoga puta obratile smo posebnu pozornost i prikazale ih na primjeru ove mikroregije.

Kulturološka komponenta kao sastavnica "duha prostora” snažno prožima agroturizam tj. elementi etnologije provlače se kroz gotovo sve elemente ponude i aktivnosti na seoskim domaćinstvima, a nerijetko postaju i osnovna atraktivnost ambijenta koji temelje svoju originalnost upravo na uslugama sizrazitim etnološkim motivima (ibid.).

Etnologija, dakle, može doprinositi realizaciji ruralnog turizma na određenom području kroz različite sadržaje: u rekonstrukciji objekata i određenih tradicijskih djelatnosti (gospodarskih, rukotvornih i sl.), u uređenju okoliša, u gastronomiji, u odnosu s gostima, preko suvenira, običaja, vjerovanja, tradicionalnih manifestacija i dr. (usp. ibid. 39-40). Posebna uloga etnologa očituje se u objedinjavanju spomenutih resursa za turističku uporabu.

Od turizma kultura dobiva dodatni izvor prihoda (...) potiče se profesionalno upravljanje kulturnim dobrima i njihov marketing, omogućava se bolja kontrola nad korištenjem kulturnih potencijala, a među lokalnim stanovništvom stvara se bolji imidž kulture (Demonja 2006:11).

Etnolozi boravkom na terenu mogu pozitivno utjecati na odnos nositelja kulturnih dobara prema svojoj kulturnoj baštini. Sudionici istraživanja na Krivome Putu često su se susretali s nekim predmetom, koji je zbog prestanka njegove upotrebe bio u lošem stanju i nije bio adekvatno čuvan. Naše zanimanje za upravo takve predmete, potaknulo je lokalno stanovništvo da im počnu posvećivati veću pažnju, stavljati 
na istaknuta mjesta u kući te im se na taj način u očima nositelja kulture povećala vrijednost, dok su ih do nedavno podcjenjivali, ponekad ih se čak i sramili, jer su ih doživljavali kao znak zaostalosti i siromaštva. Naš višekratni boravak na Krivome Putu u razdoblju od 2003. do 2006. godine doprinio je promjeni stava naših kazivača, Krivopućana, prema svojoj baštini; predmeti koji su propadali počeli su dobivati na važnosti. Pozitivni pomaci u stavu prema tradicijskoj baštini njihovih nositelja još bi se više mogli potaknuti njihovim uključivanjem u agroturističku ponudu. Jedan od razloga takvome odnosu prema vlastitoj baštini leži i u nedovoljnoj brizi šire lokalne zajednice. O tome Blaženka Ljubović piše sljedeće:

\section{Polazeći od pretpostavke da svaki grad u svojoj opstojnosti mora biti usko povezan sa širom okolicom, tj. da bude pravo središte za pomoć i podršku naseljima na svom području, Senj je izgubio tu povezanost .... Zbog toga danas bilježimo ovakvo demografsko i gospodarsko stanje (2008: 51).}

\section{Razvoj ruralnog turizma interaktivni je proces koji uključuje mnoge segmente te zahtijeva permanentnu organizaciju, financijsku podršku i promociju (Baćac 2002:40).}

Za uspješniju realizaciju ruralnog turizma od velike važnosti je i senzibiliziranje potencijalnih financijera takvih projekata. Budući da je Vlada Republike Hrvatske usvojila Strategiju razvoja kulturnog turizma u Hrvatskoj, na državnoj razini za to već postoji razvojni okvir. Prijedlog revitalizacije Krivoga Puta uklapa se u taj okvir, čime njezino ostvarivanje postaje lakše izvedivo u praksi. Osnovni strateški cilj razvoja kulturnog turizma u razdoblju od četiriju godina je oblikovanje okružja i infrastrukture koji dugoročno potiču i usmjeravaju razvoj kulturnih turističkih inicijativa u Hrvatskoj (Demonja 2006: 12). Da bi se to konkretno postiglo u slučaju područja Krivoga Puta, nužno je uspostaviti suradnju etnoloških i drugih kulturnih institucija na razini grada Senja, Turističke zajednice grada Senja, lokalne samouprave i drugih nadležnih ustanova, privatnih poduzetnika porijeklom iz Krivoga Puta, u zemlji i inozemstvu. Dosad je već, vezano uz istraživanja tradicijske baštine ovoga kraja, uspostavljena suradnja između Odsjeka za etnologiju i kulturnu antropologiju Filozofskoga fakulteta u Zagrebu, Gradskog muzeja Senja i lokalne samouprave. Atrakcijski resursi ovoga kraja mogli bi se organizacijski povezati osnivanjem ogranaka ekomuzeja sa središtem u gradu Senju i uklopiti u već osmišljenu urbanu turističku ponudu grada Senja, što bi na općoj razini bio doprinos obogaćivanju dosadašnje turističke ponude. To pripada sferi organizacije i načina realizacije agroturističkih sadržaja.

Na lokalnoj zajednici dobrim dijelom leži odluka hoće li ova obavljena istraživanja iskoristiti za gospodarski razvoj svoje sredine. Razvoj ruralnog turizma doprinio bi razvoju grada Senja i njegova zaleđa i na širem gospodarskom planu, tako na primjer u samozapošljavanju stanovništva, čime bi se zaustavio trend depopulacije sela i poticao povratak stanovništva iz urbanih sredina u ruralne. $\mathrm{Na}$ taj bi se način moglo doprinijeti očuvanju i valorizaciji prirodne i kulturne baštine i revitalizaciji senjskog zaleđa socijalno i ekonomski, kroz izravan poticaj obnavljanja tradicijskog graditeljstva, segmenata tradicijskog gospodarstva u funkciji turističkog proizvoda, kroz poticaj proizvodnje tradicionalnih proizvoda preko razvoja maloga obiteljskog gospodarstva te poticanjem već spomenutih materijalnih i nematerijalnih sadržaja. Za sve to potrebne su predradnje koje više nisu u nadležnosti etnologa (usp. Baćac 2006: 40). Etnolog je samo jedna, rekli bismo neizostavna, karika u lancu razvoja ruralnog turizma.

Predstavljanje turističkih potencijala jedne mikroregije u zaleđu grada Senja iz ovog rada, potencijalno utječe na predstavljanje atrakcijskih resursa drugih područja senjskoga zaleđa (Senjsko bilo, Krasno, Velebitsko podgorje) u kojima su, također, slična istraživanja dobrim dijelom provedena. Postojeći model istraživanja mogao bi se primijeniti i u drugim krajevima Hrvatske, uzimajući u obzir sve prirodne, društvene i kulturne specifičnosti određene regije, kao i dosadašnja pozitivna iskustva primjene ruralnog turizma u pojedinim hrvatskim regijama. 


\section{LITERATURA:}

BAĆAC, Robert (2006): Agroturizam - tradicijske vrijednosti u funkciji turizma. U: Etnologija i kulturni turizam, ur. Tihana Petrović Leš i Tomislav Pletenac, Zagreb, 36-42.

BIRT, Danijela (2004): Transport i opskrba vodom na području Krivoga puta. Senjski zbornik 31, 159_ 188.

BIRT, Danijela (2008): Tradicijski prijevoz. U: Živjeti na Krivom Putu. Etnološko-povijesna monografija o primorskim Bunjevcima, 1. svezak, ur. Milana Černelić, Marijeta Rajković, Tihana Rubić, str. 281306.

BIRT, Danijela, DRONJIĆ, Matija (2008): Opskrba vodom. U: Živjeti na Krivom Putu. Etnološko-povijesna monografija o primorskim Bunjevcima, 1. svezak, ur. Milana Černelić, Marijeta Rajković, Tihana Rubić, str. 306 - 320.

ČERNELIĆ, Milana (2005): Pristupi istraživanju bunjevačkih identiteta. Studia ethnologica Croatica 17:25-49.

DEMONJA, Damir (2006): Institucijska mreža kulturnog turizma. U: Etnologija i kulturni turizam, ur. Tihana Petrović Leš i Tomislav Pletenac, Zagreb, 11-15.

JURČENKO, Vladimir, Vlatko SKORUP, Krešimir STANIŠIĆ, Branimir TOMLJANOVIĆ, Josip TOMLJANOVIĆ, Dragan VLAHOVIĆ (2005): Jarebica. Izdavač: Lovačka udruga Jarebica Senj, Senj.

JURKOVIĆ, Jasmina (2004): Tradicijska prehrana kao prilog poznavanju primorsko-bunjevačkog identiteta. Senjski zbornik 31:189-212.

KULIŠIĆ, Marija, Ivana VUKOVIĆ (2004): Majka Božja Snježna u pučkoj pobožnosti na području Krivoga Puta. Senjski zbornik 31:239-260.

KUŠEN, Eduard (2002): Turistička atrakcijska osnova. Zagreb: Institut za turizam.

KUŠEN, Eduard (2006): Turistička atrakcijska osnova s osvrtom na Goli otok. U: Etnologija i kulturni turizam, ur. Tihana Petrović Leš i Tomislav Pletenac, Zagreb, 43-51.

LOZICA, Ivan (1997): Hrvatski karnevali. Golden marketing, Zagreb.

LJUBOVIĆ Blaženka (2008): Zemljopisni položaj i pregled novije povijest Krivoga Puta. U: Živjeti na Krivom Putu. Etnološko-povijesna monografija o primorskim Bunjevcima, 1. svezak, ur. Milana Černelić, Marijeta Rajković, Tihana Rubić, str. 49- 68.

RAJKOVIĆ, Marijeta (2005): Sezonske migracije na području Krivoga Puta: tradicija u recentnoj povijesnoj perspektivi. Senjski zbornik 32:273-316.

RAJKOVIĆ, Marijeta (2008): Tradicijsko gospodarstvo. U: Živjeti na Krivom Putu. Etnološko-povijesna monografija o primorskim Bunjevcima, 1. svezak (Ur. Milana Černelić, Marijeta Rajković, Tihana Rubić), str. 157- 278.

ŠARIĆ ŽIC, Ivana (2006): Prikaz tradicijskog graditeljstva na području Krivog Puta. Senjski zbornik 33:353-376.

ŠARIĆ ŽIC, Ivana (2008): Tradicijsko graditeljstvo. U: Živjeti na Krivom Putu. Etnološko-povijesna monografija o primorskim Bunjevcima, 1. svezak (Ur. Milana Černelić, Marijeta Rajković, Tihana Rubić), str. 137- 154.

ŠKRBIĆ ALEMPIJEVIĆ, Nevena (2003): Prilozi poznavanju primorsko-bunjevačkog identiteta. Senjski zbornik 30:425-444.

ŠKRBIĆ ALEMPIJEVIĆ, Nevena (2006): Krivoputske poklade i senjski karnevali: uključivanje Krivopućana u ophode s maskama. Senjski zbornik 33:377-404.

VLATKOVIĆ, Aleksandra (2003): Odijevanje i tekstilno rukotvorstvo primorskih Bunjevaca. Senjski zbornik 30:587-628. 